\title{
EXPERIMENTAL STUDY OF THE INFLUENCE OF A NEOGALENICAL PHYTOCOMPLEX FROM THE SHOOTS OF LEDUM PALUSTRE ON THE COURSE OF ACUTE BRONCHITIS DISEASE IN RATS
}

\author{
Karyna Tolmachova \\ Department of Pharmacology and Pharmacotherapy ${ }^{l}$ \\ tolmacheva.karina.91@gmail.com \\ Igor Kireiev \\ Department of Pharmacology and Pharmacotherapy ${ }^{l}$ \\ ivkireev@ukr.net \\ Oleg Koshoviy \\ Department of Pharmacognosy ${ }^{l}$ \\ oleh.koshovyi@gmail.com \\ Svetlana Grashchenkova
}

Educational and Scientific Training Laboratory of Medical and Biological Research Educational and Scientific Institute of Applied Pharmacy of National University of Pharmacy 53 Pushkinska str., Kharkiv, Ukraine, 61002 grashenkovas@ukr.net

Taras Upyr

Department of Pharmacognosy froyd1856@gmail.com

${ }^{I}$ National University of Pharmacy

53 Pushkinska str., Kharkiv, Ukraine, 61002

\begin{abstract}
The aim of the experiment was to study the anti-inflammatory effect of the novogalene agent Ledum 50, obtained from Ledum palustre shoots, in a rat model of acute bronchitis.

Materials and methods. Acute bronchitis was initiated by endotracheal administration of $1 \%$ formalin solution. The effectiveness of Ledum 50 was investigated by the number of leukocytes and cell composition in isotonic BAL solution after 24 hours and after 8 days of the experiment. Serum levels of C-reactive protein (CRP), alkaline phosphatase (AP) and CIC were determined. Histological examination of the lungs was carried out.

Results. Endotracheal injection of formalin caused irritation of the trachea and bronchi, excessive formation of bronchial secretions (heavy breathing, wheezing) in all the studied groups. The lethality of animals in the OB group on the 3rd day of the experiment (1 rat) was recorded, in the studied groups there was no death. The level of leukocytes in BAL after 24 hours exceeded the index of the IC group by 9.63 times ( $p<0.05$ ), after 8 days - by 3.0 times $(p<0.05)$. In the cellular composition of BAL, there was a significant increase in granulocytes (rod- and segmented neutrophils, eosinophils), monocytes and a decrease in the lymphocyte population against the IC group. Such changes were verified in the long term ( 8 days of the experiment), which indicates an inflammatory process.

In the group of rats that received Ledum 50, leukocytes in the BAL significantly decreased, the number of monocytes and lymphocytes in the BAL decreased, the amount of CIC in the blood serum, CRP and AP normalized. In terms of effectiveness, Ledum 50 significantly exceeded the BAL values of the reference drug. The effectiveness of experimental therapy for acute bronchitis was also verified by studying the histostructure of the airways and the respiratory part of the lungs.

Conclusions. Studies confirm the favorable course of acute bronchitis with Ledum 50 monotherapy. This fact is confirmed by the results of normalization of hematological parameters, leukocytes and BAL cell composition after 7 days of treatment with the claimed agent. This is the basis for further preclinical and clinical studies with the aim of creating an oral drug for the treatment of acute bronchitis.

Keywords: acute bronchitis, formalin, rats, shoots of Ledum palustre, effervescent tablets Prospan, bronchoalveolar lavage.
\end{abstract}




\section{Introduction}

Acute bronchitis (AB) is characterized by acute inflammation of the trachea and large bronchi without signs of pneumonia. In $90 \%$ of cases, the causative agents of the disease are viruses, much less bacteria, such as: Mycoplasmapneumoniae, Bordetellapertussis and Chlamydiapneumoniae $[1,2]$. AB can also develop due to damage to the lungs by vapors of hydrogen sulfide, chlorine, ammonia, organic dust and other toxic substances. The dominant signs of AB are cough, possible wheezing, shortness of breath, nasal congestion, headache, fever, the radiograph shows an expansion of the roots of the lungs [3]. According to the guidelines on the basis of evidence-based medicine, drug therapy for the treatment of acute bronchitis includes symptomatic treatment of cough, and it is recommended to take antitussive drugs and expectorants [4]. In our opinion, it is rational to use herbal medicines, because herbal medicines act on the mechanism of development of acute bronchitis, reducing inflammation in the respiratory tract $[5,6]$. In addition, they have a number of advantages: polytherapy, safety, efficacy and cost-effectiveness $[7,8]$. In the pharmaceutical market of Ukraine you can find many herbal medicines that are used and intended for the treatment of cough in acute bronchitis. However, according to the literature, a limited number of drugs have a strong evidence base and are recommended for use by European colleagues. The effectiveness of ivy and thyme has been clinically proven [9-12], but ivy-based drugs are quite expensive, and thyme-based drugs have a number of contraindications, such as: diseases of the gastrointestinal tract (hyperacid gastritis, peptic ulcer disease), cardiovascular disease system (in atrial fibrillation, atherosclerosis, hypertension), in addition, the essential oil of thyme is a strong irritant to the renal parenchyma [13]. Since these diseases are very relevant - the use of thyme is limited.

Therefore, further search for new herbal medicines is promising. Our attention was drawn to a plant that has long been used in folk medicine for the treatment of respiratory diseases - shoots of Ledum palustre. It is known that Ledum palustre enhances the secretion of bronchial glands, increases the activity of the ciliated epithelium of the respiratory tract, has an antispasmodic effect on the smooth muscles of the bronchi, providing expectorant, enveloping and antitussive effect, has antimicrobial activity. Due to the poisonous properties of the plant today, its use is limited - the essential oil, which is part of the plant, causes headaches, dizziness, nausea. In the study, it was decided to obtain a new galenic phytocomplex based on the shoots of Ledum palustre, which due to its purification from ballast substances will not have a toxic effect on the body. Previous studies have proved the author's assumptions (experimental study of acute toxicity and the study of the effect of phytocomplex No. 5 on the behavioral and emotional response in rats) [14, 15].

That is why the shoots of Ledum palustre are useful as promising plant raw materials for the creation of new drugs in the treatment of diseases of the respiratory system. It is also worth noting that Ledum palustre has a raw material base in Ukraine. There are resources in the territory of Western Polissya (Volyn and Rivne regions) [16, 17].

The aim of the experiment was to investigate the anti-inflammatory effect of the new galenic agent Ledum 50, obtained from the shoots of Ledum palustre in a model of acute bronchitis in rats.

\section{Materials and methods}

At the Department of Pharmacognosy of the National University of Pharmacy under the leadership of prof. Koshovyi O. M., the method of multiple extraction of Ledum palustre shoots with $50 \%$ ethanol [18], obtained a new galaxy phytocomplex of Ledum palustre shoots (hereinafter - Ledum 50), which includes polyphenolic compounds - $13.47 \%$, flavonoids - $12.34 \%$, monosaccharides $-4.79 \%$, carboxylic acids $-2.96 \%$, hydroxycinnamic acids $-1.78 \%$, terpene compounds $-1.33 \%$ and amino acids $-0.31 \%$. In experiments on guinea pigs, Ledum 50 showed a pronounced antitussive and bronchodilator effect at a dose of $50 \mathrm{mg} / \mathrm{kg}[19,20]$.

The next step in the study was to examine the effectiveness of Ledum 50 in acute bronchitis in rats [21]. White outbred female rats obtained from the vivarium of the Educational And Scientific Institute Of Applied Pharmacy of NUPh were selected for the study. Animals were kept in a room with controlled microclimate parameters: air temperature $+18-22^{\circ} \mathrm{C}$, relative humidity 50-65\%, light regime «12 hours day/night» [22]. Animals were treated in accordance with the rules of the «European Convention for the Protection of Vertebrate Animals Used for Experimental 
and Scientific Purposes» (Strasbourg, 1986) [23]. The study protocol of Ledum 50 on the model of acute bronchitis was agreed with the local committee on bioethics «Commission on Bioethics of the National University of Pharmacy», Protocol No. 2 dated November 4, 2019,

All experimental animals except intact were modelled with AB. As the initiating agent used $1 \%$ formalin solution, which was administered endotracheally at a dose of $2 \mathrm{ml} / \mathrm{animal}$ using a probe for endotracheal administration under anesthesia (thiopental $38 \mathrm{mg} / \mathrm{kg}$, intraperitoneally) (certificate No. 001528 from 15.03.2020). Animals were divided into groups: the first - intact control (IC, 6 animals), the second - animals with simulated acute bronchitis (AB, 6 animals); groups 3 and 4 - animals that received simulated $\mathrm{AB}$ received Ledum 50 at a dose of $50 \mathrm{mg} / \mathrm{kg}$ (6 animals) [10] and the comparison drug (CD) effervescent tablets Propan at a dose of $240 \mathrm{mg} / \mathrm{kg}$ (6 animals), respectively. Effervescent tablets Prospan (p.19N066A, Germany), were transferred from the daily dose for humans using the conversion factor [24].

Test samples were administered intragastrically once daily in a volume of $1 \mathrm{ml} / 100 \mathrm{~g}$, group $\mathrm{AB}$ animals received distilled water in an equivalent volume. Treatment was started 24 hours after modelling AB for 7 days.

To assess the intensity of airway inflammation 24 hours (peak pathology) after AB initiation [21], 6 animals from the group of intact control and the group with simulated AB were removed from the experiment. The level of leukocytes and ESR was determined in the peripheral blood of control rats, in the isotonic solution of BAL - leukocytes and the cellular composition of washes by conventional methods [25-27].

To study the effectiveness of treatment from the experiment, the animals were removed on the 8th day of the experiment under light chloroform anesthesia and bronchoalveolar lavage was taken, blood was collected for biochemical parameters and lung tissue was taken for histological examination.

The pharmacotherapeutic effect of the samples was determined by serum biochemical parameters - the level of C-reactive protein (CRP), the activity of alkaline phosphatase (AP) and circulating immune complexes (CIC) using diagnostic kits (LLC NPL «Granum», Ukraine).

Fragments of the main (extrapulmonary) and intrapulmonary bronchi and bronchioles, respiratory department of lungs of rats of all experimental groups were used for histologic researches. Histological preparations were made according to the recommendations [28]. Examination of micropreparations was performed using a Granum microscope, microphotography - a digital video camera Granum DSM 310, photographs were processed on a Pentium 2.4 GHz computer using Toup View.

All actual material was processed by methods of variation statistics (mean value $(M)$, its standard error $(m)$ using parametric (one-way analysis of variance ANOVA, Newman-Keuls test) and non-parametric methods of analysis (Kruskal-Wallis test, Mann-Whitney test)). The accepted significance level is $p<0.05$, and the standard STATISTICA software package (version 6) was used to obtain statistical conclusions [29-31].

\section{Research results}

Endotracheal administration of formalin caused irritation of the trachea and bronchi, excessive formation of bronchial secretions (difficulty breathing, wheezing) in all experimental groups. Mortality of animals was recorded on the 3rd day of the experiment only in group AB (1 rat), in the experimental groups there was no death (Table 2).

Swelling and hemorrhage were observed in the bronchi during macro-examination. In group $\mathrm{AB}$, the level of leukocytes in BAL (Table 1) after 24 hours exceeded this figure by 9.63 times $(p<0.05)$, after 8 days -3.0 times $(p<0.05)$. When assessing the cellular composition of BAL in these terms, a significant increase in granulocytes (segmental and rod-shaped neutrophils, eosinophils) and monocytes, a decrease in the population of lymphocytes relative to the IC group (Table 1). In all treated groups of animals, BAL leukocytes were significantly reduced against the AB group to the level of the IR group. Indicators of cell composition in the group receiving Ledum 50 were close to those of group IC (monocytes and lymphocytes), the total granulocyte showed a tendency to decrease. Prospan also had a similar effect, some indicators (segmental neutrophils, monocytes, lymphocytes) were even inferior to Ledum 50. 
The inflammatory process initiated by formalin, naturally led to an increase in the serum of animals CRP level, an important marker of bronchopulmonary diseases [32, 33], which is logically correlated with the maximum value of leukocytes in group AB (Table 1). In animals of group Ledum 50 the value of this indicator was significant against group AB and had no significant deviations from the values of group IC. A similar effect is shown in the Prospan CD group. No deviations between the study groups were found.

Table 1

The effect of Ledum 50 and the comparison drug Prospan on the level of leukocytes and cell composition of isotonic BAL solution in acute bronchitis in rats $(M \pm m)$

\begin{tabular}{|c|c|c|c|c|c|c|}
\hline \multirow[t]{2}{*}{ Indicators } & $\begin{array}{l}\text { Intact } \\
\text { control }\end{array}$ & $\mathbf{A B}$ & $\begin{array}{l}\text { Intact } \\
\text { control }\end{array}$ & $\mathbf{A B}$ & $\mathrm{AB}+$ Ledum 50 & AB + Prospan \\
\hline & \multicolumn{2}{|c|}{24 hours } & \multicolumn{4}{|c|}{7 days of treatment } \\
\hline Blood leukocytes, $10^{9} / 1$ & $12.42 \pm 0.62$ & $16.85 \pm 0.60 *$ & $12.21 \pm 0.50$ & $14.70 \pm 0.46^{*}$ & $13.29 \pm 0.72$ & $13.21 \pm 0.68$ \\
\hline $\mathrm{ESR}, \mathrm{mm} / \mathrm{h}$ & $1.66 \pm 0.17$ & $4.90 \pm 0.40^{*}$ & $1.58 \pm 0.24$ & $3.30 \pm 0.30^{*}$ & $2.25 \pm 0.28 \mathrm{t} * / * *$ & $2.50 \pm 0.18 * / * *$ \\
\hline Leukocytes BAL, 109/1 & $0.19 \pm 0.03$ & $1.83 \pm 0.29^{*}$ & $0.24 \pm 0.07$ & $0.76 \pm 0.30 *$ & $0.34 \pm 0.02 * *$ & $0.36 \pm 0.06 \mathrm{t}^{* *}$ \\
\hline Neutrophils: segmental BAL & $4.40 \pm 1.03$ & $39.33 \pm 8.64 *$ & $4.40 \pm 1.03$ & $18.60 \pm 2.23^{*}$ & $1.20 \pm 0.20 * / * * / * * *$ & $5.00 \pm 0.32 * / * *$ \\
\hline Neutrophils: rod-shaped BAL & $3.40 \pm 0.40$ & $30.17 \pm 4.09 *$ & $3.40 \pm 0.40$ & $26.80 \pm 4.68^{*}$ & $8.00 \pm 0.45 * / * *$ & $8.40 \pm 0.51 * / * *$ \\
\hline Eosinophils BAL & $3.00 \pm 0.78$ & $22.50 \pm 3.28^{*}$ & $3.00 \pm 0.78$ & $18.60 \pm 2.48 *$ & $12.20 \pm 0.80 * / * *$ & $14.60 \pm 0.87^{*}$ \\
\hline Granulocytes BAL & $10.80 \pm 1.16$ & $92.00 \pm 9.53^{*}$ & $10.80 \pm 1.16$ & $64.00 \pm 6.49 *$ & $21.40 \pm 0.51 * / * * / * * *$ & $28.00 \pm 0.63 * / * *$ \\
\hline Monocytes BAL & $7.20 \pm 1.02$ & $32.00 \pm 2.27 *$ & $7.20 \pm 1.02$ & $29.60 \pm 2.46^{*}$ & $8.60 \pm 1.03 * * / * * *$ & $14.00 \pm 1.22 * / * *$ \\
\hline Lymphocytes BAL & $85.40 \pm 6.39$ & $285.67 \pm 25.63^{*}$ & $85.40 \pm 6.39$ & $180.60 \pm 12.34^{*}$ & $101.80 \pm 4.69^{* *} / t^{* * *}$ & $119.40 \pm 6.42 * / * *$ \\
\hline
\end{tabular}

The severity of the humoral response was not enhanced in animals with $\mathrm{AB}-\mathrm{CIC}$ was significantly reduced against the IC group (Table 2). Against the background of 7-day treatment with Ledum 50, this figure increased (8th day of the experiment), which is possible in the treatment of bronchopulmonary diseases, especially in the late period, both in experiments and in the clinic [34-36]. It can also be assumed that high levels of CIC are observed in experimental groups in which the immune response was more effective. The AP index in group AB responded to intoxication of animals with significant IC values for animals. 7-fold administration to animals of the studied drugs reduced the manifestations of intoxication, but did not fully recover them. No deviations between the study groups were found.

Table 2

Effect of Ledum 50 and effervescent tablets Prospan on biochemical parameters in the serum of rats after 7 days of treatment in acute bronchitis $(M \pm m)$

\begin{tabular}{ccccc}
\hline Indicators & Intact control & AB & AB + Ledum 50 & AB + Prospan \\
\hline Survival, $\%$ & 100 & 83 & 100 & 100 \\
CRP, g/1 & $7.00 \pm 1$ & $19.20 \pm 2.94^{*}$ & $10.00 \pm 1.27^{* *}$ & $8.00 \pm 1.27^{* *}$ \\
CIC, c.u. & $0.070 \pm 0.003$ & $0.055 \pm 0.003^{*}$ & $0.068 \pm 0.003$ & $0.063 \pm 0.002$ \\
AP, nmol/1 & $4.22 \pm 0.25$ & $7.33 \pm 0.31^{*}$ & $4.87 \pm 0.23 t^{*} / * *$ & $5.14 \pm 0.23^{*} / * *$
\end{tabular}

Note: * - statistically significant values for IC group, $p<0.05$; ** - statistically significant values for group AB, $p<0.05$; $t$ - the value is close to statistical, $0.05<p<0.100$

At microscopic research at rats of IC group the wall of the main bronchial tubes (at the level of bifurcation) was presented by mucous, submucous, fibrocartilage and external covers. The mucous 
membrane was lined with multilayered ciliated epithelium with a moderate number of goblet cells. The own plate of a mucous membrane was presented moderately, subepithelially contains a capillary grid. The submucosal membrane consists of loose connective tissue, variable saturated with cellular material. The fibrocartilage shell contains not closed annular cartilaginous plates. The space between the plates was filled with bundles of smooth muscle cells with connective tissue layers, in which places are moderately represented lymphoid clusters (Fig. 1). Large and medium bronchi have cartilaginous plates. The lumen of the bronchi and bronchioles is quite wide. In the stroma of the bronchial tree lymphoid clusters were of various sizes. In the pulmonary parenchyma, the pattern of alveolar passages, alveolar cavities and sacs was normal, signs of dystelectasis and atelectasis, proliferative manifestations of interalveolar septa were not observed.

In group $\mathrm{AB}$ rats on day 8 of the experiment had hyperplasia of the epithelium of the main and large intrapulmonary bronchi, violation of the structure of the flickering apparatus (loosening of the apical parts of the flickering cells), infiltration of the mucous and submucosal layers of the bronchial wall (Fig. 2). Among the ciliated epithelium, a marked increase in goblet cells with glycosaminoglycans was observed (Fig. 3). The epithelial lining of the middle and small bronchi was not changed, but in the terminal bronchioles increased focal desquamation of epithelial cells was observed. Increased lymphocytic perebronchial reaction in the stroma of the bronchial tree, focal clusters of lymphocytic cells perivascularly were found. Alveolar pattern of lung tissue was not changed, in some rats observed some thickened interalveolar septa (Fig. 4). The listed changes in lungs of rats of group $\mathrm{AB}$ are well coordinated with shifts of cellular structure in BAL (Table 1).

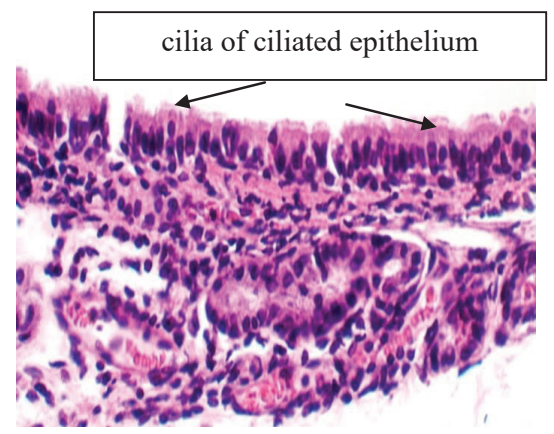

Fig. 1. A fragment of the wall of the main bronchus of an intact rat. Normal condition of the ciliated epithelium, stroma of the mucous membrane. Hematoxylin-eosin. $\times 400$

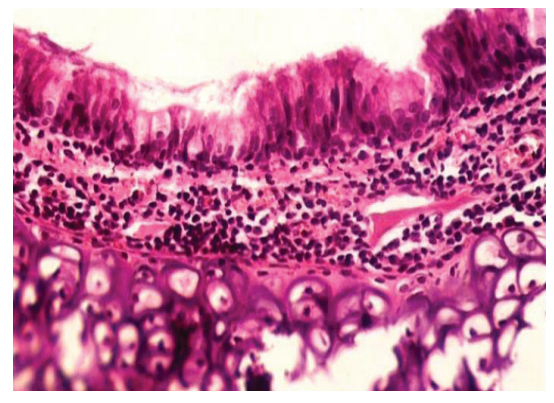

Fig. 2. The wall of the main bronchus of rats from group AB. Epithelial hyperplasia, focal disturbance of the structure of the flickering apparatus, infiltration of the mucous and submucosal layers by inflammatory infiltrate cells. Hematoxylin-eosin. $\times 250$

Ledum 50 therapy helped to minimize the signs of hyperplasia of the epithelium of the main and large intrapulmonary bronchi, disorders of the structure of the flickering apparatus (Fig. 5). However, there were clusters of goblet cells, focal infiltration of the mucous and submucosal layers of the bronchial wall, increased lymphocytic peribronchial response, perivascular infiltration (Fig. 6). In animals treated with Prospan, a similar microscopic picture was observed 
as in the Ledum 50 group - there were almost no signs of bronchial epithelial hyperplasia. No differences were found between the groups.

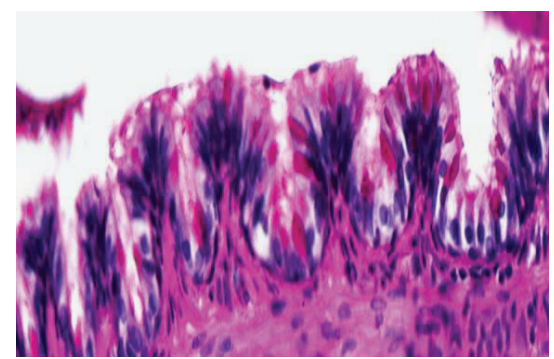

Fig. 3. The wall of the large intrapulmonary bronchus of the rat from group AB. An increase in the number of goblet cells among the ciliated epithelium. PAS-reaction according to McManus. $\times 400$

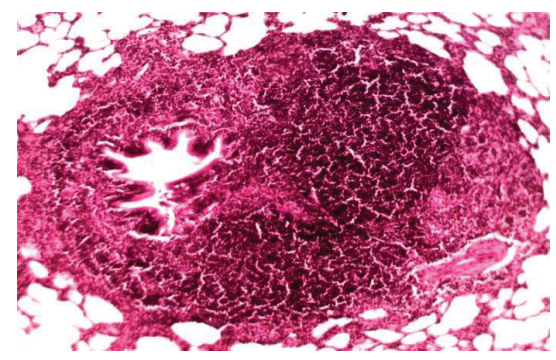

Fig. 4. The respiratory tract of rat lung tissue from group AB. Hypertrophy of peribronchial lymphocytic infiltrate. Hematoxylin-eosin. $\times 100$

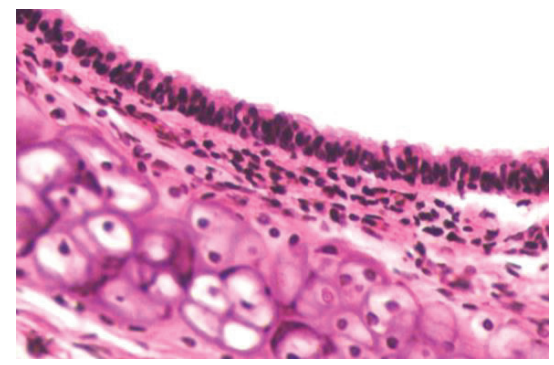

Fig. 5. The wall of the main bronchus of rats from the group Ledum 50: normal state of the ciliated epithelium. Hematoxylin-eosin, $\times 200$

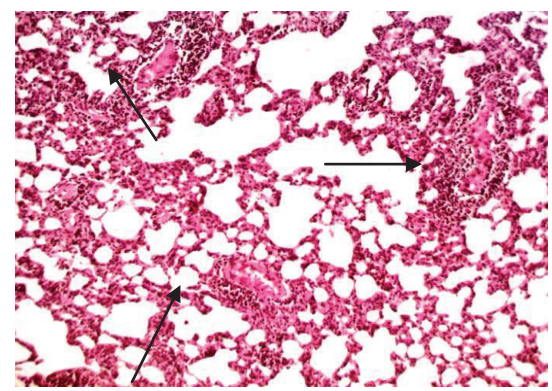

Fig. 6. Respiratory lung tissue of rats from the group Ledum 50: perivascular lymphocytic infiltration $(d)$. Hematoxylin-eosin, $\times 100$

Almost a similar microscopic picture was observed after therapeutic administration of the comparison drug (Fig. 7), which indicates that the studied phytocomplex-leader from the shoots of Ledum palustre for some positive therapeutic effect on the histological condition of the bronchi after intratracheal administration of $1 \%$ formalin solution is not inferior to the comparison drug. 


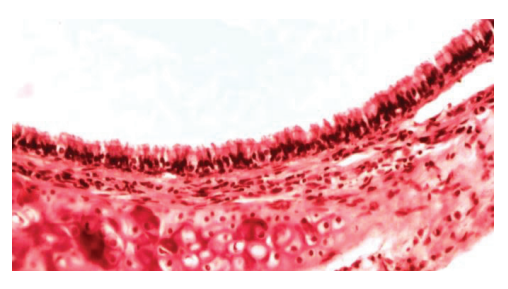

$a$

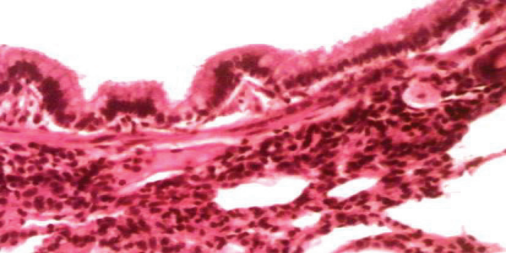

b

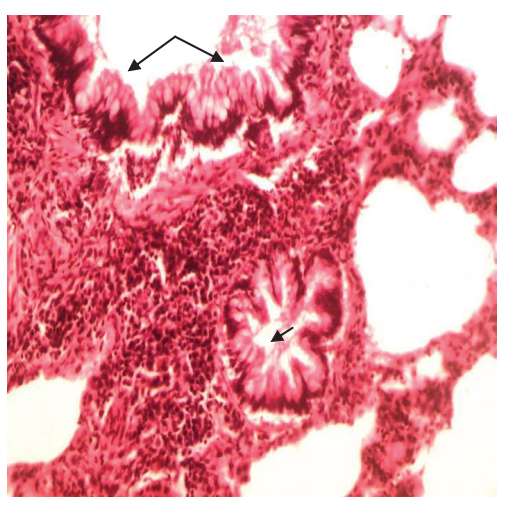

c

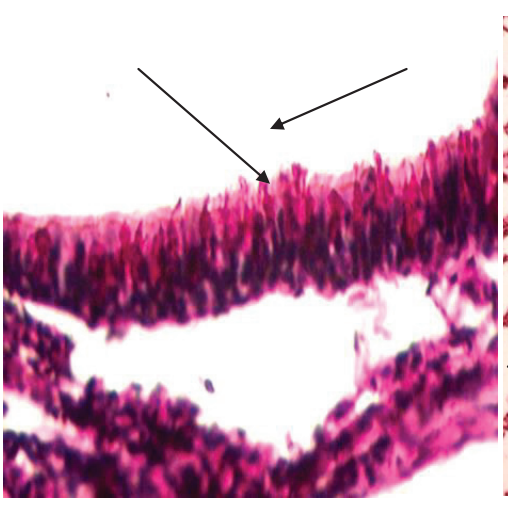

$d$

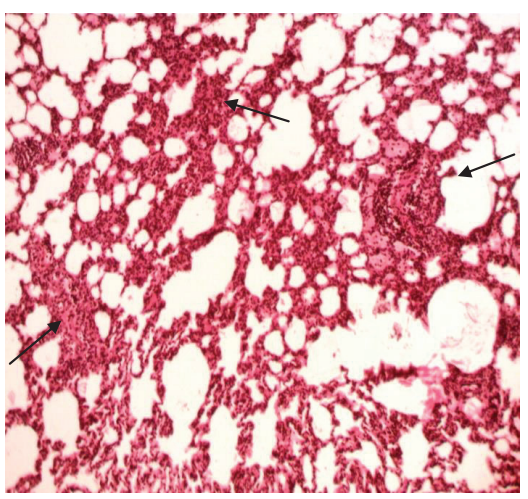

Fig. 7. Fragment of the wall of the main $(a)$ and large intrapulmonary $(b, c, d)$ bronchus, respiratory lung tissue (e) of the rat after treatment with the comparison drug Prospan: the condition of the ciliated epithelium is normal $(a, b)$, a marked increase in the number of goblet cells among the ciliates middle bronchi $(c, d)$, lymphocytic infiltration of the submucosal layer (c), perivascular lymphocytic infiltration (e): $a, b, c, d$-hematoxylin-eosin, d PAS reaction according to McManus x. $a, c-\times 200 ; b-\times 250 ; d-\times 400 ; e-\times 100$

\section{Discussion of research results}

A new galenic phytocomplex was obtained from the shoots of Ledum palustre, which is a light brown substance that was dissolved in distilled water for pharmacological research. To obtain the phytocomplex №5 were used extraction with $50 \%$ ethanol, for efficiency and maximum removal of BAS, which was proposed for the first time in contrast to previous studies [37].

According to the results of our study, 7-day treatment of rats with the proposed drug Ledum 50 at a dose of $50 \mathrm{mg} / \mathrm{kg}$, which simulated acute bronchitis, significantly normalized hematological parameters, leukocytes and cell composition of BAL. Histological examination showed that no differences were found between the experimental group and the reference group. Which suggests that Ledum 50 has anti-inflammatory properties at the level of the drug Prospan. Thus, the prospects of further preclinical and clinical studies and the creation of a modern, safe, effective, economical, domestic drug for the treatment of acute bronchitis have been proven.

Study limitations. The content of leukotrienes and prostaglandins was not studied.

Prospects for further research. A number of experimental studies Ledum 50 proves its viability for further preclinical and clinical studies to develop an effective and safe drug for the pathogenetic treatment of acute bronchitis, which has a polytherapeutic effect on the body.

\section{Conclusions}

Endotracheal administration of $1 \%$ formalin solution causes bronchopulmonary inflammation, which changes the histostructure of the lungs and bronchi on day 8 corresponds to the picture of acute toxic bronchitis. Modelling of $\mathrm{AB}$ caused mobilization of leukocytes in broncho-alveolar lavage fluid. Its maximum severity was observed in the dynamics after 24 hours and after 8 consecutive days, an increase in leukocytes and in the cellular composition of BAL. The main sign of an acute inflammatory process was a marked increase in CRP, AP against a background of reduced immune protection - CIC.

New galenic phytocomplex Ledum 50, obtained from shoots of Ledum palustre, at a dose of $50 \mathrm{mg} / \mathrm{kg}$, which was administered intragastrically to rats in a treatment regimen for 7 days, significantly reduced leukocytes in BAL, restored the number of monocytes and lymphocytes in 
BAL, the indicators did not differ significantly from intact animals, normalized the number of immune complexes in serum, CRP and AP.

The results of the study confirm the favourable course of inflammatory disease on the background of Ledum 50 in monotherapy. Normalization of the histostructure of the respiratory system in animals treated with Ledum 50 is apparently due to the complex action of the phytocomplex, which has a strong anti-inflammatory effect, which is proven in the model of acute bronchitis and zymosan and carrageenan edema in rats (previously studied). It should be noted that the phytocomplex No. 5 is able to inhibit the synthesis of prostaglandins and leukotrienes, which will allow the pathogenetic therapy of acute inflammation of the bronchial mucosa.

\section{Conflict of interests}

The authors declare that they have no conflicts of interest.

\section{References}

[1] Graham, W. (2018). Acute bronchitis. Can Fam Physician, 54, 238-239.

[2] Sanjay, S. (2020). Acute Bronchitis. Available at: https://www.msdmanuals.com/professional/pulmonary-disorders/acute-bronchitis/acute-bronchitis

[3] Unyfykovanyi klinichnyi protokol pervynnoi medychnoi dopomohy. «Kashel u doroslykh». Available at: https://kiai.com.ua/ua/ archive/2016/3 \%2892 \%29/pages-38-45/unifikovaniy-klinichniy-protokol-pervinnoyi-medichnoyi-dopomogi-kashel-u-doroslih-

[4] Nastanovy na zasadakh dokazovoi medytsyny. Nastanova 00129. Available at: https:/guidelines.moz.gov.ua/documents/3030

[5] Kemmerich, B., Eberhardt, R., Stammer, H. (2011). Efficacy and Tolerability of a Fluid Extract Combination of Thyme Herb and Ivy Leaves and Matched Placebo in Adults Suffering from Acute Bronchitis with Productive Cough. Arzneimittelforschung, 56 (9), 652-660. doi: http://doi.org/10.1055/s-0031-1296767

[6] Wagner, L., Cramer, H., Klose, P., Lauche, R., Gass, F., Dobos, G., Langhorst, J. (2015). Herbal Medicine for Cough: a Systematic Review and Meta-Analysis. Complementary Medicine Research, 22 (6), 359-368. doi: http://doi.org/10.1159/000442111

[7] Yershova, I. B., Osypova, T. F. (2016). General Requirements to the Preparation of Tinctures, Decoctions. Dosage of Phytopreparations. Actual Infectology, 3 (12), 123-127. doi: http://doi.org/10.22141/2312-413x.3.12.2016.81727

[8] Harnik, T. P., Andriichuk, L. V., Harnik, K. V., Matsko, V. O., Petrysheva, V. O. (2018). Fitozasoby pry hostrykh respiratornykh zakhvoriuvanniakh ta nespetsyfichnykh zakhvoriuvanniakh orhaniv dykhannia. Fitoterapiia. Chasopys, 1, 19-25.

[9] Schaefer, A., Ludwig, F., Giannetti, B. M., Bulitta, M., Wacker, A. (2019). Efficacy of two dosing schemes of a liquid containing ivy leaves dry extract EA 575 versus placebo in the treatment of acute bronchitis in adults. ERJ Open Research, 5 (4), 00019-2019. doi: http://doi.org/10.1183/23120541.00019-2019

[10] Holzinger, F., Chenot, J.-F. (2011). Systematic Review of Clinical Trials Assessing the Effectiveness of Ivy Leaf (Hedera Helix) for Acute Upper Respiratory Tract Infections. Evidence-Based Complementary and Alternative Medicine, 2011 , 1-9. doi: http://doi.org/10.1155/2011/382789

[11] Cwientzek, U., Ottillinger, B., Arenberger, P. (2011). Acute bronchitis therapy with ivy leaves extracts in a two-arm study. A double-blind, randomised study vs. an other ivy leaves extract. Phytomedicine, 18 (13), 1105-1109. doi: http://doi.org/10.1016/ j.phymed.2011.06.014

[12] Hecker, M., Runkel, F., Voelp, A. (2002). Treatment of chronic bronchitis with ivy leaf special extract--multicenter post-marketing surveillance study in 1,350 patients. Forsch Komplementarmed Klass Naturheilkd, 9 (2), 77-84. doi: http:// doi.org/10.1159/000057269

[13] Chebrets. Farmatsevtychna entsyklopediia. Available at: https://www.pharmencyclopedia.com.ua/article/75/chebrec

[14] Tolmachova, K., Kireyev, I., Tsemenko, K., Koshovoyi, O. (2019). Preclinical Study of Acute Toxicity of the Neogalenical phytocomplex from Ledum palustre shoots. Recipe, 22 (5), 688-694.

[15] Tolmachova, K. S., Kireyev, I. V., Koshoviy, O. M., Tsemenko, K. V., Botsula, I. V. (2019). The study of the emotional and behavioral response in rats after introduction of the neogalenical phytocomplex from Ledum palustre shoots. Clinical pharmacy, 23 (3), 48-51. doi: http://doi.org/10.24959/cphj.19.1499

[16] Minarchenko, V. M. (2013). The resources of medicinal plants of the Western Polissya: state, use and trends of dynamics. Naukovyi visnyk NLTU Ukrainy, 23 (13), 20-23.

[17] Gluschenko, L. A. (2014). The influence of some ecological factors on the crop value of Ledumpalustre L. coenopopulations. Chornomorskyi botanichnyi zhurnal, 10 (1), 6-14.

[18] Koshovyi, O., Upyr, T., Komissarenko, A. (2016). Phytochemical and pharmacological study of the dry extract of Labrador tea shoots. History, Problems and Prospects of Development of Modern Civilization. Tokyo: Tokyo University Press, 382-385. 
[19] Tolmachova, K. S., Kireiev, I. V., Koshovyi, O. M., Upyr, T. V., Tolmachova, K. S. (2019). Pat. No. 139206 UA. Novohalenovyi fitokompleks z protykashlovoiu diieiu. MPK: A61K 36/45, A61K 47/10, A61K 11/14. No. u 2019 06433; declareted: 10.06.2019; published: 26.12.2019, Bul. No. 24, 3.

[20] Tolmachova, K. S., Kireiev, I. V., Koshovyi, O. M., Upyr, T. V., Tsemenko, K. V. (2019). Pat. No. 142410 UA. Zastosuvannia novohalenovoho fitokompleksu pahoniv Bahna zvychainoho yak bronkholitychnoho zasobu dlia likuvannia hostroho bronkhitu. MPK: A61K 36/45, A61R 11/08, A61R 11/06 No. u 2019 09844; declareted: 16.09.2019; published: 10.06.2020, Bul. No. 11, 3.

[21] Katelnikova, A. E., Kryshen, K. L., Makarov, V. G., Vorobeva, V. V., Pozharitskaia, O. N., Shikov, A. N. (2014). Poisk novykh protvovospalitelnykh sredstv na osnove kompleksa glikolizirovannykh peptidov, vydelennykh iz morskikh ezhei vida strongilocentrotus droebachiensis. Obzory po klinicheskoi farmakologii i lekarstvennoi terapii, 14 (4), 9-15.

[22] Kozhemiakin, Yu. M., Hromov, O. S., Filonenko, M. A., Sayfetdinova, H. A. (2002). Naukovo praktychni rekomendatsii z utrymannia laboratornykh tvaryn ta roboti z nymy. Kyiv: Avitsena, 156.

[23] Yevropeiska konventsiia pro zakhyst khrebetnykh tvaryn, shcho vykorystovuiutsia dlia doslidnykh ta inshykh naukovykh tsilei (1986). Strasburh. Available at: https://zakon.rada.gov.ua/laws/show/994_137\#Text

[24] Ulanova, I. P., Sidorov, K. K., Khalepo, A. I.; Letavet, A. A.; Sanotskii, I. V. (Eds.) (1968). K voprosu ob uchete poverkhnosti tela eksperimentalnykh zhivotnykh pri toksikologicheskom issledovanii. Kyiv- Leningrad: Meditsina, 10, 18-25.

[25] Menshikov, V. V., Delektorskaia, L. N., Zolotnitskaia, R. P. (1987). Laboratornye metody issledovaniia v klinike. Moscow: Meditsina, 367.

[26] Zinovev, S. V., Semenova, G. V., Tseluiko, S. S., Chzhou, S. D., Li, Ts. (2014). Tsitokhimicheskaia kharakeristika lokalizatsii kationov kaltsiia natriia $\mathrm{v}$ kletkakh indutsirovannoi mokroty i bronkhoalveoliarnoi lavazhnoi zhidkosti u bolnykh bronkhialnoi astmoi. Biulleten fiziologii i patologii dykhaniia, 52, 52-56.

[27] Meyer, K. C., Raghu, G., Baughman, R. P., Brown, K. K., Costabel, U., du Bois, R. M. et. al. (2012). An Official American Thoracic Society Clinical Practice Guideline: The Clinical Utility of Bronchoalveolar Lavage Cellular Analysis in Interstitial Lung Disease. American Journal of Respiratory and Critical Care Medicine, 185 (9), 1004-1014. doi: http://doi.org/10.1164/ rccm.201202-0320st

[28] Merkulov, G. A. (1969). Kurs patologogistologicheskoi tekhniki. Moscow: Meditsina, Leningr. otd-nie, 424.

[29] Lapach, S. N., Chubenko, A. V., Babich, P. N. (2001). Statisticheskie metody v mediko-biologicheskikh issledovaniiakh S ispolzovaniem Excel. Kyiv, 320.

[30] Osnovnye metody statisticheskoi obrabotki rezultatov farmakologicheskikh eksperimentov (2000). Rukovodstvo po eksperimentalnomu (doklinicheskomu) izucheniiu novykh farmakologicheskikh veschestv. Moscow: Remedium, 349-354.

[31] Rebrova, O. Iu. (2006). Statisticheskii analiz meditsinskikh dannykh. Primenenie paketa programm Statistica. Moscow: MediaSfera, 312.

[32] Standartnie tsitopreparati bronkhoalveoliarnogo lavazha v issledovanii i patologii legkikh. Available at: http://www.clinlab.ru/ win/LIBRARY/JOURNLAB/lab6/j6ct2.htm

[33] Feschenko, Iu. I., Golubovska, O. A., Goncharov, K. A. (2012). Negospitalna pnevmoniia u doroslikh osib: etiologiia, patogenez, klasifikatsiia, diagnostika, antibakterialna terapiia (proekt klinichnii nastanov). Ch. I. Ukrainskii pulmonologichnii zhurnal, 4, 5-13.

[34] Cazzola, M., Rogliani, P., Aliberti, S., Blasi, F., Matera, M. G. (2017). An update on the pharmacotherapeutic management of lower respiratory tract infections. Expert Opinion on Pharmacotherapy, 18 (10), 973-988. doi: http://doi.org/10.1080/1465656 6.2017.1328497

[35] Nazar, O. V., Andrianova, I. V., Titomir, A. I., Kuznetsov, L. V. (2008). Immunologicheskie aspekty vnegospitalnoi pnevmonii. Klinichna imunologiia, alergologiia, infektologiia, 5-2. Available at: https://kiai.com.ua/ru/archive/2008/5-2/article-230/ immunologicheskie-aspekty-vnegospitalnoy-pnevmonii

[36] Reheda-Furdychko, M. M., Reheda, S. M., Furdychko, L. O. (2016). Derangement of some immune values in blood at late period of experimen-tal pneumonia and thiotriazolin correctio. Odeskyi medychnyi zhurnal, 3, 9-11.

[37] Izotov, D. V., Tagiltsev, Iu. G., Kolesnikova, R. D. (2005). Tekhnologiia polucheniia i fiziko-khimicheskie kharakteristiki bagulnikovoi kondensatsionnoi vody. Tr. DalNIILKH, 38, 6-14.

Received date 15.01.2021

(C) The Author(s) 2021

Accepted date 09.03.2021

Published date 31.03.2021

This is an open access article under the CC BY license (http://creativecommons.org/licenses/by/4.0).

How to cite: Tolmachova, K., Kireiev, I., Koshoviy, O., Grashchenkova, S., Upyr, T. (2021). Experimental study of the influence of a neogalenical phytocomplex from the sprouts of ledum palustre on the course of acute bronchitis disease in rats. EUREKA: Health Sciences, 2, 64-72. doi: http://doi.org/10.21303/2504-5679.2021.001712 